\title{
THE GEOPOLITICAL CONSEQUENCES OF THE COVID-19: A CATALYST FOR AN ASIAN-PACIFIC CENTRE OF GLOVAL SUPERPOWER
}

\author{
Ana Belén Perianes Bermúdez ${ }^{18}$ \\ The University Institute General Gutiérrez Mellado-UNED, Madrid
}

\begin{abstract}
Before the COVID-19 pandemic outbreak, the world was in a process of transition from the unipolar system which had ruled the world since the end of the Cold War to an increasingly multilateral order. With this regard, there was a kind of consensus between academics, decision-makers and other interested actors in the international arena in the sense that the world was transitioning towards a much more multipolar order in which the US would lose gradually its status of the only superpower for the benefit of mainly China but also for other Asian-Pacific states. The aim of this paper is to examine the extent of the consequences of the COVID-19 at the geopolitical level in the framework of global power redistribution. In this sense, this paper will analyse if the COVID-19 pandemic has significantly altered the US and Chinese social, economic and political scenarios in the framework of the great power competition and also if the pandemic will substantially shift the geopolitical balance of the world. This study will try to answer which have been the effects of the pandemic in terms of geopolitics and the prospects of its impact on the global power redistribution and international leadership competition at the short and medium term. In this sense, the main question to be answered in this research is: Has the COVID-19 pandemic lead to a faster than previously expected Western loss of economic and political power able to lead to new world order transition dynamics with significant consequences for the international security architecture?
\end{abstract}

Keywords: Geopolitics, COVID-19, Asia-Pacific, Great Powers Competition, Global Power Transition.

\section{Introduction}

The 21st century will stand out for some global existential crises. Among them, we will focus on the spread of the disruptive impacts of the COVID-19 pandemic around the world since the end of 2019 thanks to globalization. Undoubtedly, this pandemic has resulted in one of the most serious global crisis since the Second World War with very important economic, political and health implications around the globe. COVID-19 global recovery will be fostered by the relative success of vaccines, social and political action around the world

But besides, the pandemic outbreak took place during a process of global order transition to an increasingly multilateral international system, with a deepening of great superpowers competition between the US and China. In this context, liberal democracies and the US global leadership role are being more and more questioned and contested mainly by countries as China, Russia or Turkey, among others. It is worth stressing that there is

${ }^{18}$ Contact address: aperianes@igm.uned.es 
since almost two decades ago a kind of consensus between academics, decision-makers and other interested actors in international relations in the sense that the world is transitioning towards a multipolar order in which the US will gradually lose at the medium and long term its status of superpower for the benefit of mainly China but also for other Asian-Pacific states (such as India).

The COVID-19 outbreak created incentives for the US and China for both cooperation to overcome as soon as possible the global health crisis and its effects around the world and competition over access to the required resources and information for recovery (Mussington, 2020). Nevertheless, since the beginnings of the pandemic, competition among great (and medium-sized) powers concerning to the origins and the required measures to fight against the impact of this crisis strained relations among them.

Furthermore, in the current context of global order transformation we face towards an increasingly multilateral international system and fragmentation of power to the detrimental of liberal democracies, the great global and regional powers, especially the US, China and Russia, but also the EU, are particularly interested in the growing relevance of the Asian continent as a whole due to its added geostrategic value (in demographic, economic and energy terms, among other ones of relevance). In this regard, Asia-Pacific will be the region that will grow the most at the global level in the coming decades (Organisation for Economic Cooperation and Development-OECD).

From an ideological perspective, it should be highlighted how divergent are the approaches of the main global and regional powers competing in the global arena. This is especially important given the fact that the US and other Western powers as the EU $($ Saari 2019,7$)$ are promoting for instance their own understandings of connectivity. These values and principles are fully inspired in the values and principles of the liberal democracies (V-Dem Institute 2020, 10). With this respect, liberal democracy is understood as a form of government with representative democracy and free and fair forms of elections (competitive political processes with plural political parties); a constitutional democracy; the primacy of the rule of law; separation of powers (judicial, legislative and executive); press freedom and, the protection of individual and human rights.

By contrast, China and Russia have opposing political systems of governance. For its part, China's form of government is a communist state, where the Chinese Communist Party is the leading political party in the country, being a rigidly organized political force that controls and leads society at all levels. Secondly, Russia is technically a federal semi-presidential republic with a president, prime minister, three branches of government (executive, legislative and judicial) and a legislature. These two states are classified as authoritarian regimes based on their electoral processes and pluralism, civil liberties, the functioning of government, political participation and political culture (The Economist Intelligence Unit Limited, 2021, 30-35).

Clearly, this fact impacts on the way in which these states influence at the global and regional level through the implementation of hard and soft power politics and trying to protect their national interests.

The aim of this paper is to examine the extent of the consequences of the COVID-19 at the geopolitical level in the framework of global power redistribution. In this sense, this paper will analyse if the COVID-19 pandemic has significantly altered the US and Chinese social, economic and political scenarios in the framework of the great power competition and 
also if the pandemic will substantially shift the geopolitical balance of the world. This study will try to answer which have been the effects of the pandemic in terms of geopolitics and the prospects of its impact on the global power redistribution and international leadership competition at the short and medium term. In this sense, the main question to be answered in this research is: Has the COVID-19 pandemic lead to a faster than previously expected Western loss of economic and political power for the benefit of China able to lead to new world order transition dynamics with significant consequences for the international security architecture?

The article is structured as follows: after the introduction, we will find a point dedicated to the analysis of the global order before the COVID19 outbreak, the systemic rivalry among the US and China and the US rebalancing of global power in the $21^{\text {st }}$ century towards Asia-Pacific for approaching the object of study. Then, this study analyses the impact of the COVID-19 on geopolitics and the global power redistribution, offering responses to the research question above explained. Lastly, the present article makes the concluding remarks which summarises the main ideas concluded from this analysis by the author

Finally, it is noteworthy that this research has been limited by the relative short time since the COVID-19 outbreak and by the uncertainty derived from the fact that the world has not yet overcome this global health crisis and its depth socioeconomic impacts, with different levels of intensity and effects among countries and regions. International cooperation will be vital to restoring public confidence and recovering from this pandemic in terms of global economy (Royal Institution of Chartered Surveyors, 2020). Also, the geopolitical rivalry between the two global superpowers (the US and China) are in constant evolution. In this context, their systemic competition is also conditioned by the role played by other countries and regional actors (such as Russia, Turkey or the EU for instance) and by key topical international events, such as the US withdrawal from Afghanistan in August 2021.

\section{The global order before the Covid-19 outbreak. the systemic rivalry among the US and China and the US rebalancing of global power in the 21st century towards Asia-Pacific}

According to Thompson $(2020,11)$, the systemic rivalry among the US and China is becoming the prime mover of global affairs. After the impact of the so-called global war on terrorism launched by the George W. Bush Administration (2001-2009), it became clear during the first years of the Obama Administration (2009-2016) that the US no longer had the power or the capacity to unilaterally implement policies of international scope and that this kind of actions would require the support of other great or medium powers. In this way, the US could influence but not control other parts of the world due to its relative loss of power (Nye, 2011, 218-220). However, in the face of the emergence or impulse of new regional and global powers, the US remains as a superpower with the greatest capabilities on key issues such as security and defence capabilities, soft power or technology, among others, and will continue to play a central role in the global balance of power in the coming decades.

Since 2011, the US made official the rebalancing of its economic, political and security priorities towards Asia-Pacific. In this sense, it was the Obama Administration the one which formally launched in November 2011 the rebalancing of forces prioritizing the resources available for diplomacy, trade and security in the Asia-Pacific region in the framework of 
an institutional visit to Australia (Obama, 2011). The US avoided using the term Pivot (in reference to the so-called "Pivot to Asia" policy, replacing it with the concept of rebalancing to avoid expectations of a greater reordering of the country's strategic priorities (Silove, 2016, 45). At the same time, this issue has been a cause for concern on this side of the Atlantic because Europeans have traditionally benefited from US support for security and defence, including NATO capabilities.

Accordingly, it was implicitly recognized by the US the end of its global primacy and the existence of a new structure in the framework of the international system with new poles of power in which the centre of gravity of world affairs was shifting from the Western Atlantic to Asia-Pacific. Thus, the US faced the challenge of regaining its previous global reputation and leadership within the context of a new balance of powers in the transitional process to multipolarity while still being a superpower. This forced the Obama Administration to reformulate its global strategy based on a pragmatic realism and a change in strategic priorities (relocation and concentration of advanced forces and interests in the Asia-Pacific region, to the detriment of other areas such as Europe or the East).

Although the term "Asia" is used in the framework of this US foreign policy, China is the country who clearly captures the US attention by constituting itself as the only power in the region with the capacity to challenge its global hegemony (Etzioni 2012, 1). The US need to reassure alliances with its partners and allies in the region within the framework of the new Chinese assertiveness ( $\mathrm{Li}, 2021,2)$ led the Obama Administration to reinforce its military presence in the region within the framework of its global policy rebalancing of forces (Anderson; Cha, 2017, 609). However, this US policy could not be described as "containment" or "conflict" (Hosseini; Mousavi; Heikal, 2018, 634).

The strategic and geopolitical relevance of the Asia-Pacific region is clear. For its part, China is in progressive expansion with its Belt and Road Initiative (BRI), which has been thought as a huge number of development and investment projects whose aim is to build and enhance connectivity from East Asia to the European continent, expanding China's global economic and political influence. Although there is no official list of participants to date, Chatzky and McBride (2020) estimate that more than sixty states (which account for two-thirds of the world's population) have signed BRI projects or expressed their interest in closing agreements.

China approaches the issue of "connectivity" in the BRI core document "Vision and Actions on Jointly Building Silk Road Economic Belt \& 21st-Century Marime Silk Road"1" (Belt and Road Forum for International Cooperation). Regarding this Chinese concept of connectivity, China's government outlines its willingness to foster green and low carbon infrastructure construction and operation management to preserve natural environments and to protect the countries in the route from negatives impacts of climate change. Peopleto-people bonds related to the BRI are also mentioned as a priority topic of this initiative. But it is noteworthy that the above indicated aspects are not being largely taken into account in practice (Geeraerts, 2019, 3). Related to this issue, some participant countries are particularly being affected by debt traps, an increase of public and private corruption or environmental problems as a result of the implementation of BRI related projects in their territories, with limited benefits for their own citizens.

${ }^{19}$ Detailed information can be consulted at http://beltandroadforum.org/english/n100/2017/0410/ c22-45.html 
Some key data confirms the process of power transition that is taking place from the West to Asia-Pacific. Firstly, the International Monetary Fund estimates that China has become the world's largest economy in terms of GDP based on purchasing power parity (although the US remains as the global leader in GDP per capita). It is noteworthy that medium and long-terms projection of real GDP between the two countries shows a clear advantageous position for China. OECD real GDP long-term forecast for 2060 estimates a total of 38974320 million US dollars for the US and 62591470 for China ${ }^{20}$. The demographic concentration in this region is also very significant, with 1.37 billion inhabitants in China, 1.299 billion in India and 622 in the ASEAN countries (Association of Southeast Asian countries). It is worth stressing that China accounts for $31.69 \%$ of Asia's total population and over $18 \%$ of the world's population. For its part, India has the $29.36 \%$ of the continent's population and $17.5 \%$ of the world's population (World Population Review). In addition, it is noteworthy the importance of this region as a world hub in terms of trade and maritime traffic. For instance, according to the United Nations Conference on Trade and Development (UNCTAD), Asia is the largest seaborne trading region. In this connection, Asian seaports handled 4.5 billion tons of goods loaded, and 6.9 billion tons of goods unloaded, while the rest of continents recorded much smaller volumes. In sum, Asia-Pacific is expected to lead the world economy and production in 2050 (PwC). Logically, the nerve centre of the global economy is shifting from the West Atlantic to the Asia-Pacific region.

The US rebalancing of forces towards Asia-Pacific would seek to focus on these long-term strategic opportunities for the country in these areas, given the above-mentioned expected relevance of this region during the next decades in economic, demographic, diplomatic and security terms (Davidson, 2014, 78). In this connection and through consensus policy, the successive US administrations have sought to establish a strategic continuity scenario with different tactics (Hoseini; Mousavi; Heikal, 2018, 664) that guides possible Chinese strategic choices in a manner favourable to their interests.

To this end, the US would seek to strengthen bilateral relations with Australia, Japan, the Philippines, South Korea, and Thailand; to strengthen relations with emerging regional powers, including India, Indonesia and China; strengthening the role of the US in multilateral regional institutions, such as the Association of Southeast Asian Nations (ASEAN) or the AsiaPacific Economic Cooperation Mechanism (APEC); to expanding US trade and investment in the region, through for example, the Trans-Pacific Economic Cooperation Agreement (TPP); to promote the continued presence of US military personnel in areas of Japan, South Korea, Australia or Singapore, and to seek the advancement of human rights and liberal democracy in the region (Clinton, 2011).

The current US Administration with Biden as president openly recognizes China as its main systemic rival ${ }^{21}$. There are several reasons for his position on China: a) The violation of human rights in the case of the situation of the Muslim minority of Uyghurs in re-education camps in Xinjiang (China); b) The trade war inherited from the Trump Administration; c) Chinese assertive actions in Taiwan and the South China Sea; d) The accusations of cyberattacks by China; e) Strategic dependence on China in key sectors; $f$ ) The strategic dependence of the US

${ }^{20}$ This data consulted is available at https://data.oecd.org/gdp/real-gdp-long-term-forecast. htm\#indicator-chart (accessed on 27 August 2021).

${ }^{21}$ As it can be seen in the Interim National Security Strategic Guidance, online https://www.whitehouse. gov/briefing-room/statements-releases/2021/03/03/interim-national-security-strategic-guidance/ 
on China in key sectors; g) US accusations of theft of intellectual property by China or, h) The electoral reform in Hong Kong, which makes the role of the democratic opposition symbolic. This causes a setback in the "broad autonomy" that Beijing promised to grant Hong Kong as an autonomous territory until 2047, among other main reasons.

\section{The impact of the covid-19 on geopolitics and the global power redistribution}

Has the COVID-19 pandemic the potential to change the global order dynamics (including geopolitical realignments) which were ruling the international system before the crisis outbreak at the end of 2019? How major and regional powers respond at the short and medium term to the pandemic and its impact will be key in geopolitical terms. This results from the fact that its outcomes could reshape the balance of hard and soft power with respect to great and regional powers global influence, economic performance, defence capabilities or social cohesión, among other issues of interest.

Because of that, the pandemic should be not only addressed in terms of health and socioeconomic problems or national and international security, but also from the point of view of its geopolitical impact derived from how the countries and supranational political organisations have managed (decreased or accumulated) their power. This is related to how the states will be able to emerge from the crisis and to overcome the debt generated during this global health crisis. Most importantly, this debt will cause a redistribution of power (this is mainly the case for emerging countries) (EsadeCenter for Leadership, 2020).

The global recovery from the COVID-19 continues underway in the midst of international uncertainty. With this respect, this pandemic is fostering a change on the global balance of power increasing the gap between emerging countries and the advanced economies including China.

From the beginning of the COVID-19 outbreak, competition among great and mediumsized powers concerning to the origins and the required measures to fight against the impact of the pandemic strained relations among them. And regarding the attempts to advance on the recovery from the COVID-19 pandemic, they are marked by national governments priorities and previous rivalries.

It is expected that the global economic environment will suffer from a weakened industrial globalization. Changes made by the states and international organizations such as also the EU to attempt to become their own strategic providers and the greater need and use of digital tools might lead to a new revolution in terms of technological globalized connectivity and a greater increase in commerce exchanges (being even much more necessary the cybersecurity capacities (Al-Rodhan 2020).

Trends linked to a greater deceleration of globalisation seem to have arisen in the framework of the US and China strategic rivalry on trade, technology, geostrategy or, on security and defence affairs, among other key issues. COVID-19 impact has led to an increase in competitive dynamics and established supply chains (such as the related to corporate partnerships or technology markets) have begun to be altered due to the US Administration de-linkage strategy to disconnect national vital economic sectors from technologies, goods and services from China and, as a result, because to the Chinese response to this fact (Mussington, 2020).

There are four vital products in the framework of the global competition among these 
two superpowers: semiconductors, minerals and rare earths, pharmaceuticals and advanced batteries. These kind of products are indispensable to manufacture electric car motors, wind turbines, sophisticated devices, chips, or strategically important defence applications in geopolitical competition, among others. In this respect, it should be noted that China accounts for a very significant part of the production of semiconductors and rare earths, which produces tension and instability in the market. The production power of these materials is meant as a weapon in geopolitical or commercial disputes (Szczepański, 2021, 2).

Achieving independence in terms of control and ownership of supply chains in critical sectors and distribution of these products will be essential for both the US and China to be les dependable on foreign players (Biscop, 2020a). This pandemic has exposed the high level of dependence on the global supply chains ${ }^{22}$ of these essential products, showing the need of the countries to be their own providers of national strategic goods and services. This seems to be leading to a greater geo-economic rivalry to the detrimental of cooperation (EsadeCenter for Leadership, 2020).

But as Biscop (2020b) states, the COVID-19 crisis has not repeated the 2008 financial scenario, in which China was able to take advantage of the lack of investment from US and EU sources. In this sense, the strong dependency of global markets leads to the fact that powers are interested in a minimal recovery of the others to avoid risks for themselves. It would be a question of reorganizing globalisation, not about redo it as deep economic interdependence among powers will remain. The accelerating industrial development that is taking place around the world requires the availability of high amounts of natural resources, in particular hydrocarbons and strategic minerals. The above mentioned ones are critical for high technology industrial processes, especially in terms of space, communications, armament or sophisticated devices, but also to build infrastructures or other goods in the framework of the global fight against climate change (Baños, 2011, 1-2). These materials are scarce in most parts of the world and where they are available, their extraction is very expensive and difficult, and they are in the hands of very few countries or in really unstable and fragile contexts. As a result, it is indispensable for interested actors/powers (including states and multinational companies) to gain access to a significant amount of these kind of materials.

In this regard, due to its strategic relevance and the topical of the issue when these lines are being written (second half of August 2021), it should be noted that Afghanistan has huge amounts of minerals of key significance (such as gold, cooper, iron ore, cobalt, rare earth elements, lithium, uranium, hydrocarbons, chromium, talc, lead, zinc, precious stones, sulphur, graphite, aluminium, silver, lapis lazuli, asbestos or phosphorus, among other resources of interest) (Shaieq; Nakaza; Carolyn, 2019).

These key natural resources have of course caught the international attention of different states and actors, which compete for obtaining their control to satisfy their national and political/economic strategic priorities. It should be outlined that the access to these natural

${ }^{22}$ Regarding the US strategic dependence on China, President Biden ordered in February 2021 the re-evaluation of the US strategic global supply chains so as not to depend on the production and imports of "foreign rivals" (clear reference to China).

More information can be found at:

https://www.whitehouse.gov/briefing-room/presidential-actions/2021/02/24/executive-order-onamericas-supply-chains/ 
resources will depend on the taliban, the warlords, the organized crime or the terrorist threat, among others, and their interests, under a context of structural violence, corruption, a massive violation of people's (particularly women and children) human rights and, a generalized human insecurity (Shah, 2020).

The US withdrawal from Afghanistan has made much more possible great strategic gains for China (Malemnganba, 2021). This fact makes Afghanistan a key geopolitical strategy and investment target for China. It would be a great strategic advantage for China to access to key natural resources (also taking into account that the Chinese lead the supply and distribution chains of rare earth material). Also, this would better allow Chinese BRI projects towards Pakistan within the framework of its systemic rivalry with the US. Nevertheless, China and also Russia should worry about potential spill-over of instability and insecurity linked to the current situation in Afghanistan. Furthermore, it is worth stressing to note that the politically-driven narratives around conspiracy theories over-politicizing the impacts of the pandemic in the framework of the US-China rivalry seems to have exacerbated mutual distrust and divergent values and interests (Yu, 2020). In this sense, the COVID-19 pandemic outbreak just led to a narrative escalation between these two great powers competitors on international trade, military control over territories or human rights affairs, among others on interest (Abatis; Schäublin, 2020).

At the start of the pandemic outbreak (end of 2019) during president Trump's mandate, the US did not showed the required leadership to address this global health crisis, which could be seen as an opportunity given to China to emerge as a global leader in terms of soft power despite being an authoritarian regime.

In the meanwhile, the Chinese government launched an intensive public diplomacy campaign of global leadership and soft power to fight against this unprecedented challenge, emerging as a vital supplier of critical healthcare equipment and material for the countries which were being most affected by this coronavirus. Having said that, it should be pointed out that this supply were to a large extent trade agreements rather than donations.

\section{The US and Chinese global leadership at the beginning of the COVID-19 outbreaks}

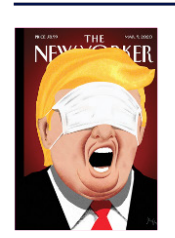

$\rightarrow$ Pays no attention to alerts

$\rightarrow$ Fails to recognise the importance of the threat

$\rightarrow$ Does not act in time

$\rightarrow$ Announces that "We have the virus totally under control"

$\rightarrow$ Predicts that with the warmer weather of April, the virus will "miraculously disappear"

$\rightarrow$ Does not lead the coordination of the crisis either at international or state level

$\rightarrow$ Insists on calling the virus the "Chinese virus"

$\rightarrow$ Unilaterally imposes a travel ban on his European "allies"

$\rightarrow$ Imposes increasingly strict sanctions on

Iran in the middle of the pandemic

$\rightarrow$ Paralyses the G7

$\rightarrow$ Suspends funding to the WHO

$\rightarrow$ Refuses to lead the organisation of aid to

other countries

$\rightarrow$ Tries to monopolise access to the

COVID-19 vaccine by buying a German

pharmaceutical company (CureVac)

$\rightarrow$ Suggests administering disinfectant into

the body to kill the virus

$\rightarrow$ Refuses to take part in the launch of a

global drugs and vaccines initiative

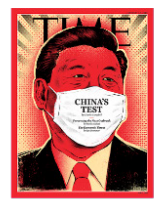

$\rightarrow$ Fails to halt trade in wild animals

$\rightarrow$ Reacts late

$\rightarrow$ Conceals the beginning of the epidemic and

the real data on people affected

$\rightarrow$ Suppresses the truth

$\rightarrow$ Promotes a propaganda campaign and a diplomatic offensive that has little or no credibility

$\rightarrow$ Sends planes loaded with protective masks, test kits, ventilators, respirators and medical staff

$\rightarrow$ Offers knowledge transfer

$\rightarrow$ Supports the WHO with a contribution of $\$ 50 \mathrm{~m}$

Source: EsadeCenter for Leadersip 
Moreover, it is important to explain that geo-economics are directly linked to the geopolitics of the COVID-19 crisis. During the first year of the COVID-19 pandemic, it seemed that this global health crisis would increase more rapidly than expected in previous medium term forecasts the Western loss of economic and political power, leading to a much more accelerated global order transition with the Chinese world primacy. In relation to that formulation, China would overtake the U.S. as the world's largest economy much earlier during this decade due to the kind of measures developed by both countries to fight against the impacts of the pandemic during 2020 ( $\mathrm{Xu}, 2021)$.

Data shows that global economy is projected to grow at record speed, although uneven across sectors, countries and income levels (PwC, 2021). In this regard, despite key actions to recover from this pandemic taken by most policymakers, economic and societal changes brought by the COVID-19 health crisis outbreak and governments'responses to this challenge will cause structural shifts accelerating preexinting trends (Royal Institution of Chartered Surveyors, 2020) mainly for emerging market economies and low income developing countries, but not so much in terms of great powers competition.

\section{Overview of the World Economic Outlook Projections. April 2021. International Monetary Fund.}

\begin{tabular}{|c|c|c|c|c|}
\hline & \multicolumn{4}{|c|}{ Year over Year } \\
\hline & \multirow[b]{2}{*}{2019} & \multirow[b]{2}{*}{2020} & \multicolumn{2}{|c|}{ Projections } \\
\hline & & & 2021 & 2022 \\
\hline World Output & 2.8 & -3.3 & 6.0 & 4.4 \\
\hline Advanced Economies & 1.6 & -4.7 & 5.1 & 3.6 \\
\hline United States & 2.2 & -3.5 & 6.4 & 3.5 \\
\hline Euro Area & 1.3 & -6.6 & 4.4 & 3.8 \\
\hline Germany & 0.6 & -4.9 & 3.6 & 3.4 \\
\hline France & 1.5 & -8.2 & 5.8 & 4.2 \\
\hline Italy & 0.3 & -8.9 & 4.2 & 3.6 \\
\hline Spain & 2.0 & -11.0 & 6.4 & 4.7 \\
\hline Japan & 0.3 & -4.8 & 3.3 & 2.5 \\
\hline United Kingdom & 1.4 & -9.9 & 5.3 & 5.1 \\
\hline Canada & 1.9 & -5.4 & 5.0 & 4.7 \\
\hline Other Advanced Economies ${ }^{2}$ & 1.8 & -2.1 & 4.4 & 3.4 \\
\hline Emerging Market and Developing Economies & 3.6 & -2.2 & 6.7 & 5.0 \\
\hline Emerging and Developing Asia & 5.3 & -1.0 & 8.6 & 6.0 \\
\hline China & 5.8 & 2.3 & 8.4 & 5.6 \\
\hline India ${ }^{3}$ & 4.0 & -8.0 & 12.5 & 6.9 \\
\hline ASEAN- $5^{4}$ & 4.8 & -3.4 & 4.9 & 6.1 \\
\hline Emerging and Developing Europe & 2.4 & -2.0 & 4.4 & 3.9 \\
\hline Russia & 2.0 & -3.1 & 3.8 & 3.8 \\
\hline Latin America and the Caribbean & 0.2 & -7.0 & 4.6 & 3.1 \\
\hline Brazil & 1.4 & -4.1 & 3.7 & 2.6 \\
\hline Mexico & -0.1 & -8.2 & 5.0 & 3.0 \\
\hline Middle East and Central Asia & 1.4 & -2.9 & 3.7 & 3.8 \\
\hline Saudi Arabia & 0.3 & -4.1 & 2.9 & 4.0 \\
\hline Sub-Saharan Africa & 3.2 & -1.9 & 3.4 & 4.0 \\
\hline Nigeria & 2.2 & -1.8 & 2.5 & 2.3 \\
\hline South Africa & 0.2 & -7.0 & 3.1 & 2.0 \\
\hline \multicolumn{5}{|l|}{ Memorandum } \\
\hline World Growth Based on Market Exchange Rates & 2.4 & -3.6 & 5.8 & 4.1 \\
\hline European Union & 1.7 & -6.1 & 4.4 & 3.9 \\
\hline Middle East and North Africa & 0.8 & -3.4 & 4.0 & 3.7 \\
\hline Emerging Market and Middle-Income Economies & 3.5 & -2.4 & 6.9 & 5.0 \\
\hline Low-Income Developing Countries & 5.3 & 0.0 & 4.3 & 5.2 \\
\hline
\end{tabular}

Source: World Economic Outlook. Managing Divergent Recoveries. April 2021. Full Report. International Monetary Fund. Page 29. 
The available International Monetary Fund (IMF) economic forecast from April $2021^{23}$ states that the economic recovery seems to be solid and that it should be faster than it was expected in previous forecasts due to a major improvement in economic activity (industry or trade, among other elements). According to the IMF, the projections for the global economy in 2021 and 2022 are 0.8 percentage point and 0.2 percentage point stronger than in its October 2020 World Economic Outlook, this is, the outturns are being higher than expected for most regions in the second half of last year.

In global terms, thanks to a strong policy response, the COVID-19 recession is likely to leave smaller scars than the $2008 \mathrm{global}$ financial crisis. This has been possible thanks to additional fiscal support in a few large economies (especially the US), to the power of vaccine to recovery and to the adaptation of economies after lockdowns to new ways of working (International Monetary Fund, 2021, 15-19). According the World Bank (2021), among major economies, U.S. growth is projected to reach $6.8 \%$ during 2021, reflecting large-scale fiscal support and the easing of pandemic restrictions. With respect to the growth in other advanced economies, the World Bank notes that it is also firming, but to a lesser extent. Among emerging markets and developing economies, China is anticipated to rebound to $8.5 \%$ this year, which is explained by the release of pent-up demand.

Updated data (from July and August 2021) show that the economic and fiscal incentives adopted by the Biden Administration during the first months of his mandate have improved in the US the existing positive expectations of recovery (Bureau of Economic Analysis, 2021). In the meanwhile, the Chinese have seen their economic growth slowed but other key figures such the related to their foreign direct investment strong in the second quarter of the year (National Bureau of Statistics of China, 2021) (Dezan Shira \& Associates, 2021).

Nevertheless, IMF economic forecast data shows worrisome information and a number of uncertainties linked specifically to new COVID-19 variants. This results from the fact that the recovery remains unequal among countries and regions because the pandemic has increased previous divergences in income per capita across economies and persistent growth inequalities. Emerging market economies and low income developing countries have been hit harder by the pandemic and they are expected to suffer more relevant medium-term losses as these states entered the health crisis in a weak fiscal context to mobilise public finances and with low capacity to address major health care policy responses or support livelihoods. Lagging vaccination among low-income countries and the effects of the pandemic have reversed previous advances in poverty reduction and increased insecurity and other long standing challenges (World Bank, 2021).

The projected recovery in low-income countries follows a severe contraction with especially negative employment and earnings impacts on particular much vulnerable groups, such as the youth, women, workers with relatively lower educational background or the informally employed, among others. Because of that, many low-income countries are expected to only return to pre-pandemic levels in 2023 (International Monetary Fund, 2021, 43).

23 It can be consulted at: https://www.imf.org/en/Publications/WEO/Issues/2021/03/23/worldeconomic-outlook-april-2021 


\section{Conclusions}

After one year and a half since the COVID-19 outbreak, it is considered that this event did not radically impacted on international politics in terms of systemic rivalries among the US and China. The impacts of the global health crisis did not significantly affect the international balance among great powers and, before this pandemic it had already been demonstrated that Asia-Pacific will be nerve centre in the next decades to come. Key questions related to international security issues will need to be answered in the future. For instance: how will impact the US withdrawal from Afghanistan not only in the regional security but also at the global level? Will China really benefit from the US withdrawal from Afghanistan in terms of strategic gains? Will Western powers keep considering China as a revisionist power? Will China act as a revisionist power to pursue its strategic goals?

In addition, the COVID-19 crisis shed light on the need of powers to reassess international supply chains reorganizing some basis of globalisation to reduce dependency on other countries, particularly geopolitical rivals and their allies. This will clearly impact on the increase of inequalities, the quality of employment and the strength of public welfare among other key issues in affected communities, especially on the most vulnerable people. This could be related to relocations of industries, goods or services and its impacts on societies.

Finally, the rationale would have imposed coordinated and massive scientific-evidence based responses at the international level, transparency, political coordination and global solidarity (particularly in the framework of the COVAX mechanism). But emerging markets and developing countries are again the big losers of a global big crisis (in terms of quality employment, gender equality, opportunities to generate income, to receive education, human security, quality of life, etc.). Great powers should have done better on this issue.

\section{References}

Abatis, K.; Schäublin, E. (2020). Infectious Narratives: US, China and COVID-19. Center for Security Studies blog, ETH Zürich. https://isnblog.ethz.ch/corona/infectious-narratives-uschina-and-covid-19.

Al-Rodhan, N. (2020). Meta-Geopolitics of Pandemics: The Case of Covid-19, Global Policy Journal. https://www.globalpolicyjournal.com/blog/08/05/2020/meta-geopolitics-pandemics-case-covid-19.

Anderson, N. D.; Cha, V. D. (2017). The Case of the Pivot to Asia: System Effects and the Origins of Strategy, Political Science Quarterly, Volume 132, Number 4, 2017-2018. https://onlinelibrary. wiley.com/doi/abs/10.1002/polq.12703.

Baños, P. (2011). El espectro de los mineralesestratégicos (I): Afganistán, Documento Marco 03/2011, Instituto Español de EstudiosEstratégicos.

http://www.ieee.es/Galerias/fichero/docs marco/2011/DIEEEM032011MineralesAfganistan.pdf

Belt and Road Forum for International Cooperation. Vision and Actions on Jointly Building Silk 
Road Economic Belt \& 21st-Century Maritime Silk Road. http://beltandroadforum.org/english/n100/2017/0410/c22-45.html

Biscop, S. (2020a). What the coronavirus will not change, Egmont Royal Institute for International Relations. https://www.egmontinstitute.be/what-the-coronavirus-will-notchange/

Biscop, S. (2020b). Coronavirus and Power: The Impact on International Politics, Security Policy Brief N 126, March 2020, Egmont Royal Institute for International Relations.

https://www.egmontinstitute.be/coronavirus-and-power-the-impact-on-internationalpolitics/

Bureau of Economic Analysis (2021). Gross Domestic Product, 2nd Quarter 2021 (Second Estimate); Corporate Profits, 2nd Quarter 2021 (Preliminary Estimate). August 26, 2021. https://www.bea.gov/news/2021/gross-domestic-product-2nd-quarter-2021-secondestimate-corporate-profits-2nd-quarter

Chatzky, A.; McBride, J. (2020). China's massive Belt and Road Initiative, The Council on Foreign Relations https://www.cfr.org/backgrounder/chinas-massive-belt-and-road-initiative

Clinton, H. (2011). America's Pacific Century, Foreign Policy, online https://foreignpolicy. com/2011/10/11/americas-pacific-century/

Davidson, J. (2014). The US "Pivot to Asia", American Journal of Chinese Studies, June 2014, Vol. 21, Special Issue, pp. 77-82. https://www.jstor.org/stable/44289339.

Dezan Shira \& Associates (2021). China's Economic Recovery - July 2021 Economic Roundup, China Briefing, online https://www.china-briefing.com/news/chinas-economic-recovery-july2021-economic-roundup/.

EsadeCenter for Leadership (2020). Covid-19 and geopolitics: first impacts.

https://dobetter.esade.edu/en/covid-19-geopolitics-impacts

Etzioni, A. (2012). The United States' Premature Pivot to "Asia", Springer, Commentary. https:// link.springer.com/content/pdf/10.1007/s12115-012-9572-6.pdf.

Geeraerts, G. (2019). Europe and China's Belt and Road Initiative: Growing concerns, more strategy. Egmont Royal Institute for International Relations, Security Policy Brief, № 18, November 2019. https://www.egmontinstitute.be/europe-and-chinas-belt-and-roadinitiative-growing-concerns-more-strategy/.

Hosseini, H.; Mousavi, M.A.; Heikal Azad, M. K. (2018). Obama's "Pivot to Asia" Policy (20112016): the Case of China, Journal of World Sociopolitical Studies, Vol. 2, NN 4, October 2018, pp. 633-674. https://wsps.ut.ac.ir/article 70113.html.

International Monetary Fund (2021). World Economy Outlook, Managing Divergent Recoveries, April 2021. https://www.imf.org/en/Publications/WEO/weo-database/2021/April . 
Li, C. (2021). Biden's China strategy: Coalition-driven competition or Cold War-style confrontation?, Brookings Report. https://www.brookings.edu/research/bidens-china-strategy-coalitiondriven-competition-or-cold-war-style-confrontation/.

Malemnganba, A. (2021). China is the Next Empire in Afghanistan, The Geopolitics.https:// thegeopolitics.com/china-is-the-next-empire-in-afghanistan/.

Mussington, D. (2020). Covid-19 and Geopolitics, School of Public Policy, Center for Governance of Technology and Systems. https://gotech.umd.edu/research-impact/publications/covid19-and-geopolitics.

National Bureau of Statistics of China (2021). National Economy Sustained the Momentum of Stable Recovery in July, August 16, 2021. http://www.stats.gov.cn/english/ PressRelease/202108/t20210816 1820573.html .

Nye, J. (2011). The Future of Power. New York: Public Affairs.

Obama, B. (2011). Remarks By President Obama to the Australian Parliament, The White House, President Barack Obama Office of the Press Secretary.

https://obamawhitehouse.archives.gov/the-press-office/2011/11/17/remarks-presidentobama-australian-parliament .

Organisation for Economic Cooperation and Development. Real GDP long-term forecast. https://data.oecd.org/gdp/real-gdp-long-term-forecast.htm\#indicator-chart.

Royal Institution of Chartered Surveyors, (2020). COVID-19's impact on markets and geopolitics, online https://www.rics.org/north-america/news-insight/latest-news/newsopinion/covid-19s-impact-on-markets-and-geopolitics/.

Saari, S. (2019). Connecting the dots: Challenges to EU connectivity in Central Asia. Brief 6/ June 2019, European Union Institute for Security Studies online https://www.iss.europa.eu/ content/connecting-dots-challenges-eu-connectivity-central-asia

Shah, A. (2020). Afghanistan's MineralResources Are a Lost Opportunity and a Threat, The Diplomat, online https://thediplomat.com/2020/02/afghanistans-mineral-resources-are-alost-opportunity-and-a-threat/.

Shaieq, M.; Nakaza, E.; Carolyn, S. (2019). Afghanistan's Natural Resources, GSRD International Conference, online https://www.researchgate.net/publication/342344166 AFGHANISTAN'S NATURAL RESOURCES.

Szczepanski, M. (2021). Critical raw materials in EU external policies. Improving access and raising global standards, European Parliament Research Service. https://www.europarl.europa.eu/ thinktank/en/document.html?reference=EPRS BRI\%282021\%29690606. 
Silove, N. (2016). The Pivot before the Pivot: U.S. Strategy to Preserve the Power Balance in Asia, International Security, Vol. 40, No. 4 (Spring 206), pp. 45-88. https://direct.mit.edu/isec/ article/40/4/45/12127/The-Pivot-before-the-Pivot-U-S-Strategy-to.

The Economist Intelligence Unit Limited (2021). Democracy Index 2020: In sickness and in health? online https://www.eiu.com/n/campaigns/democracy-index-2020/\#mktoForm anchor.

Thompson, J. (2020). China, the US and World Order. In Key Strategic Trends 2020. Key Developments in Global Affairs. Haas and Thränert (eds), Center for Security Studies. Online: https://css.ethz.ch/content/dam/ethz/special-interest/gess/cis/center-for-securitiesstudies/pdfs/ST2020-04-BZ.pdf

United Nations Conference on Trade and Development. World seaborne trade. https://stats. unctad.org/handbook/MaritimeTransport/WorldSeaborneTrade.html

V-Dem Institute (2020). Autocratization Surges - Resistance Grow. Democracy Report 2020, Department of Political Science, University of Gothenburg, online https://www.v-dem.net/ media/filer public/de/39/de39af54-0bc5-4421-89ae-fb20dcc53dba/democracy report.pdf

World Bank (2021). Global Recovery Strong but Uneven as Many Developing Countries Struggle with the Pandemic's Lasting Effects, June 8, online https://www.worldbank.org/en/ news/press-release/2021/06/08/world-bank-global-economic-prospects-2021.

World Population Review. ASEAN countries. Online https://worldpopulationreview.com/ country-rankings/asean-countries.

PwC. The World in 2050. The long view: how will the global economic order change by 2050? https://www.pwc.com/gx/en/research-insights/economy/the-world-in-2050.html.

PwC (2021). Global economy watch: Predictions for 2021.https://www.pwc.com/gx/en/ research-insights/economy/global-economy-watch/predictions-2021.html.

Xu (2021). China's 2020 GDP means it will overtake U.S. as world's No. 1 economy sooner than expected, Fortune, January 18, 2021.https://fortune.com/2021/01/18/chinas-2020gdp-world-no-1-economy-us/.

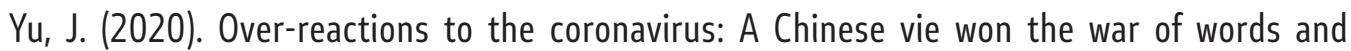
geopolitical competition, Egmont Royal Institute for International Relations.

https://www.egmontinstitute.be/over-reactions-to-the-coronavirus-a-chinese-view-on-thewar-of-words-and-geopolitical-competition/ 